\title{
Association of Vitamin D Deficiency with Low Serum Albumin in Taiwanese Older Adults with Hip Fracture: A Prospective Cross-Sectional Study
}

\author{
Ming-Hsiu CHIANG ${ }^{1}$, Yi-Jie KuO ${ }^{2,3}$, Wei-Chun $\mathrm{CHANG}^{2}$, Yueh $\mathrm{WU}^{2}$, \\ Ying-Chin LiN ${ }^{4,5,6}$, Yeu-Chai JANG ${ }^{7}$ and Yu-Pin $\mathrm{CHEN}^{2,3, *}$ \\ ${ }^{1}$ Department of General Medicine, Kaohsiung Chang Gung Memorial Hospital, Kaohsiung, Taiwan \\ ${ }^{2}$ Department of Orthopedic Surgery, Wan Fang Hospital, Taipei Medical University, Taipei, Taiwan \\ ${ }^{3}$ Department of Orthopedic Surgery, School of Medicine, College of Medicine, \\ Taipei Medical University, Taipei, Taiwan \\ ${ }^{4}$ Department of Family Medicine, School of Medicine, College of Medicine, \\ Taipei Medical University, Taipei, Taiwan \\ ${ }^{5}$ Department of Family Medicine, Wan Fang Hospital, Taipei Medical University, Taipei, Taiwan \\ ${ }^{6}$ Department of Geriatric Medicine, School of Medicine, College of Medicine, \\ Taipei Medical University, Taipei 110, Taiwan \\ ${ }^{7}$ Department of Obstetrics and Gynecology, Wan Fang Hospital, Taipei Medical University, Taipei, Taiwan
}

(Received November 11, 2020)

\begin{abstract}
Summary The world's population is aging, and the prevalence of hip fracture is rising. Vitamin D deficiency is a risk factor for hip fracture and predicts functional recovery and survival following hip fracture surgery. This cross-sectional study identified the prevalence of vitamin D deficiency in Taiwanese older patients with hip fracture and potential risk factors for vitamin D deficiency. Data from older adults with hip fracture admitted to a single medical center in Taipei, Taiwan were prospectively collected. The preoperative serum 25-hydroxyvitamin D [25(OH)D] concentration and comprehensive clinical history of each patient were examined. A multinomial logistic regression model was used to compare the clinical characteristics of deficient, insufficient, and sufficient 25(OH)D concentration groups. The cohort comprised 310 older adults with hip fracture. The mean age was $80 \pm 10 \mathrm{y}$. The deficient, insufficient, and sufficient groups comprised 180, 84, and 46 patients $(58.1 \%, 27.1 \%$, and $14.8 \%)$, respectively. Univariate analysis revealed significant intergroup differences in serum albumin level and body fat percentage and marginally significant differences in serum albumin, estimated glomerular filtration rate, body mass index, and comorbidities of affective or psychotic disorders. In the multinomial logistic regression model, albumin level was the only factor significantly correlated with higher $25(\mathrm{OH}) \mathrm{D}$ concentrations in the sufficient and insufficient groups compared with the deficient group. No variable, including preinjury functional status, was significantly correlated with vitamin D deficiency except malnutrition. Our findings may aid the establishment of a robust screening and treatment program for vitamin D deficiency.
\end{abstract}

Key Words vitamin D deficiency, hip fracture, aged, albumin, malnutrition

Because the global population is aging, the incidence of hip fracture is increasing, and such fracture is strongly associated with mortality (1). In Asia, the number of hip fractures is projected to increase from $1,124,060$ in 2018 to $2,563,488$ in 2050 , with the cost of treating hip fracture will increase from US\$9.5 to US $\$ 15$ billion (2). In 2018, Taiwan officially became an aged society; the estimated total number of hip fracture in Taiwan is projected to increase from 18,338 in 2010 to 50,421 by 2035 (3).

25 -Hydroxyvitamin D $[25(\mathrm{OH}) \mathrm{D}]$ is typically produced in the skin and is a crucial regulator of bone metabolism. It increases serum calcium concentration by inducing proteins involved in active intestinal cal-

\footnotetext{
*To whom correspondence should be addressed.

E-mail: 99231@w.tmu.edu.tw
}

cium absorption and stimulates bone calcium mobilization if the dietary intake of calcium is poor. Vitamin D deficiency causes hyperparathyroidism, which increases bone turnover and accelerates bone loss, resulting in an elevated fracture risk (4). $25(\mathrm{OH}) \mathrm{D}$ is also a prognostic predictor of functional recovery following hip fracture (5). In addition, vitamin D sufficiency improves muscle strength and is associated with better lower-extremity musculoskeletal function, which may reduce fall risk (6).

Risk factors for hip fracture include older age, lower body weight, osteoporosis, and vitamin D deficiency (7). However, data on the vitamin D status of patients with hip fracture are limited, particularly for Taiwanese older adults. In this study, we examined (1) the prevalence of vitamin D deficiency in Taiwanese older adults with hip fracture and (2) risk factors for vitamin D deficiency 
compared with those for vitamin D sufficiency or insufficiency.

\section{MATERIALS AND METHODS}

Study design. This prospective cross-sectional study recruited older adults who underwent surgery for hip fracture at a single medical center in Taipei, Taiwan. Qualifying patients were men and women aged $\geq 60 \mathrm{y}$ who had hip fracture, including intracapsular femoral neck fracture and extracapsular (i.e., basal neck, intertrochanteric, or subtrochanteric) fracture. Patients were excluded if they underwent hip surgery because of a condition other than primary hip fracture, such as osteoarthritis, trauma, tumor metastasis, infection, and avascular necrosis of the femoral head. The study complied with the code of ethics of the World Medical Association (Declaration of Helsinki) and was approved by the Ethics Committee of Taipei Medical University (TMU-JIRB N201709053). All participants provided written consent to participate and to the publication of their data.

Serum vitamin D assay. Serum from routine blood samples taken on admission was used. The total $25(\mathrm{OH}) \mathrm{D}$ level in serum and plasma was measured by performing an electrochemiluminescence assay, in which vitamin D-binding protein (DBP) was used as a capture protein to bind both 25-hydroxyvitamin D3 and 25-hydroxyvitamin D2 (Hoffmann-La Roche, Basel, Switzerland). This test is a fully automated assay for determining vitamin $\mathrm{D}$ concentration $(8)$.

Definitions of vitamin D deficiency, insufficiency, and sufficiency. In the present study, vitamin D deficiency, insufficiency, and sufficiency were defined as serum $25(\mathrm{OH}) \mathrm{D}$ concentrations of $<20,20-30$, and $>30 \mathrm{ng} /$ $\mathrm{mL}$, respectively, which are the cutoff points accepted by most experts (9). Patient data on serum 25(OH)D concentrations were collected, and the means and standard deviations were calculated. The proportions of patients with vitamin D deficiency and insufficiency were determined.

Measurement of other clinical parameters. Basic demographic data, including age, sex, and underlying comorbidities, were collected for analysis, along with preoperative laboratory data, including hemoglobin level, platelet, and white blood cell counts, the estimated glomerular filtration rate (eGFR), and parathyroid hormone and serum albumin levels. After patient consent was obtained, interviews were conducted with the patients and their caregivers on the patients' admission for hip fracture surgery. The interviews employed the Short Portable Mental Status Questionnaire (10), EuroQol-5D questionnaire (11), and Barthel Index for screening dementia, assessing preinjury quality of life, and measuring preinjury performance in activities of daily living, respectively (12). On admission, all patients also underwent screening for sarcopenia in accordance with the low handgrip strength and appendicular lean muscle mass criteria proposed by the Asian Working Group for Sarcopenia (13). Isometric grip strength, which is the maximum hand grip strength, was mea- sured using a Jamar Hydraulic Dynamometer (Sammons Preston, USA). Body fat percentage and appendicular skeletal muscle mass were normalized to size (total lean muscle mass in the upper and lower limbs divided by the body height squared). The relative appendicular skeletal muscle mass index was used to identify low muscle mass, with the threshold being $7 \mathrm{~kg} / \mathrm{m}^{2}$ for men and $5.4 \mathrm{~kg} / \mathrm{m}^{2}$ for women. The patients' bone mineral density, muscle mass, and body fat were measured through dual-energy X-ray absorptiometry.

Statistical analysis. All statistical analyses were conducted using SPSS Statistics for Windows, version 18.0 (SPSS, Chicago, IL, USA). Categorical variables are presented as frequencies and percentages, where continuous variables are presented as means \pm standard deviations. Univariate analyses were conducted on numerous potential risk factors for vitamin $\mathrm{D}$ deficiency in patients with hip fracture. The chi-square test was used to compare categorical variables, whereas analysis of variance was used to compare continuous variables. Pearson correlation analysis was conducted to analyze the relationship between vitamin D level and risk factors significant in the univariate analysis. Factors that differed significantly $(p<0.05)$ or marginally significantly $(0.05<p<0.10)$ in the univariate analysis were included in the multinomial logistic regression model for estimating odds ratios (ORs) with 95\% confidence intervals. The vitamin D deficient group was set as the reference group in the multinomial logistic regression model. For all tests, two-sided $p<0.05$ was considered statistically significant.

\section{RESULTS}

A total of 310 patients with hip fracture, comprising 87 men $(28 \%)$ and 223 women $(72 \%)$ were enrolled. The mean age was $80 \pm 10 \mathrm{y}$ (range 61-103 y). The most prevalent comorbidities were hypertension (65\%), chronic kidney disease $(30 \%)$, and diabetes mellitus (21\%). The average Charlson Comorbidity Index was $4.8 \pm 1.9$. Furthermore, $58(19 \%)$ and $133(43 \%)$ of the patients had hyperparathyroidism $(>65 \mathrm{pg} / \mathrm{mL})$ and sarcopenia, respectively. A small percentage $(3.6 \%)$ of the patients had previously had contralateral hip fracture (Table 1).

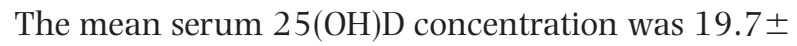
$10.7 \mathrm{ng} / \mathrm{mL}$. Overall, 180 (58.1\%), 84 (27.1\%), and 46 (14.8\%) patients had vitamin D deficiency, insufficiency, and sufficiency, respectively, with the mean serum 25(OH)D concentrations being 12.3 $\pm 4.4,25 \pm 2.8$, and $39 \pm 7.7 \mathrm{ng} / \mathrm{mL}$ (Tables 1 and 2).

As presented in Table 2, several risk factors in the three groups were compared. The results of the univariate analysis revealed significant intergroup differences in serum albumin level and body fat percentage. In addition, body mass index (BMI), eGFR, and affective or psychotic disorders exhibited marginally significant differences. Post hoc analysis results of serum albumin level and body fat percentage indicated a significantly higher serum albumin level in the vitamin D sufficient group than in the deficient group and significantly 
Table 1. Clinical characteristics of the study population.

\begin{tabular}{|c|c|}
\hline Clinical characteristics $(n=310)$ & Mean \pm SD/number (percentage) \\
\hline Age & $80 \pm 10$ \\
\hline \multicolumn{2}{|l|}{ Gender } \\
\hline Male & $87(28 \%)$ \\
\hline Female & $223(72 \%)$ \\
\hline $25(\mathrm{OH}) \mathrm{D}$ value $(\mathrm{ng} / \mathrm{mL})$ & $19.7 \pm 10.7$ \\
\hline BMI & $22.4 \pm 3.7$ \\
\hline \multicolumn{2}{|l|}{ Previous hip fracture } \\
\hline Yes & $11(3.6 \%)$ \\
\hline No & $299(96.4 \%)$ \\
\hline \multicolumn{2}{|l|}{ Underlying comorbidities } \\
\hline Hypertensions & $200(65 \%)$ \\
\hline Diabetes mellitus & $66(21 \%)$ \\
\hline Valvular heart disease & $49(16 \%)$ \\
\hline Coronary vascular disease & $52(17 \%)$ \\
\hline Chronic kidney disease & $92(30 \%)$ \\
\hline Stage IIIa & 47 \\
\hline Stage IIIb & 22 \\
\hline Stage IV & 12 \\
\hline Stage V & 11 \\
\hline Cerebral vascular accident & $40(13 \%)$ \\
\hline Peptic ulcer history & $26(8 \%)$ \\
\hline Viral hepatitis & $14(5 \%)$ \\
\hline Dementia & $53(17 \%)$ \\
\hline Affective or psychotic disorder & $19(6 \%)$ \\
\hline Parkinsonism & $18(6 \%)$ \\
\hline Cancer history & $42(14 \%)$ \\
\hline Charlson Comorbidity Index & $4.8 \pm 1.9$ \\
\hline \multicolumn{2}{|l|}{ Laboratory parameters } \\
\hline Pre-operation $\mathrm{Hb}$ & $12 \pm 1.8$ \\
\hline Platelet & $211 \pm 89$ \\
\hline WBC & $12 \pm 28$ \\
\hline eGFR & $80 \pm 35$ \\
\hline Parathyroid hormone level (pg/mL) $(n=296)$ & $54 \pm 56$ \\
\hline Hyperparathyroidism (PTH>65 pg/mL) & $58(19 \%)$ \\
\hline Albumin level $(\mathrm{g} / \mathrm{dL})(n=308)$ & $3.1 \pm 0.38$ \\
\hline \multicolumn{2}{|l|}{ Pre-injury activities of daily living } \\
\hline Barthel Index & $85 \pm 23$ \\
\hline \multicolumn{2}{|l|}{ Pre-injury quality of life } \\
\hline EQ-5D score & $0.86 \pm 0.20$ \\
\hline \multicolumn{2}{|l|}{ Bone mineral density } \\
\hline T-score $(n=300)$ & $-3.7 \pm 1.1$ \\
\hline Diagnosis of sarcopenia $(n=309)$ & $133(43 \%)$ \\
\hline Fat percentage $(n=275)$ & $33.8 \pm 7.8$ \\
\hline \multicolumn{2}{|l|}{ Living condition } \\
\hline Lives with family or in nursing homes & $286(92.3 \%)$ \\
\hline Lives alone & $24(7.7 \%)$ \\
\hline \multicolumn{2}{|l|}{ Fracture season } \\
\hline Spring & $112(36.1 \%)$ \\
\hline Summer & $73(23.6 \%)$ \\
\hline Fall & $62(20.0 \%)$ \\
\hline Winter & $63(20.3 \%)$ \\
\hline
\end{tabular}

25(OH)D, 25-hydroxyvitamin D; BMI, body mass index; WBC, white blood cells; Hb, hemoglobin; eGFR, estimated glomerular filtration rate; PTH, parathyroid hormone; EQ-5D, EuroQol-5D.

higher mean body fat percentage in the deficient and insufficient groups than in the sufficient group. Serum albumin level and body fat percentage were positively and negatively correlated with vitamin D level, respectively, whereas no significant correlations were discovered with BMI or eGFR (Fig. 1).
In the multinomial logistic regression model, serum albumin level was the only significant factor for both the insufficient and sufficient groups, with the ORs being $2.3(p=0.03)$ and $4.03(p=0.009)$, respectively, compared with the deficient group. Notably, eGFR became a significant factor between the sufficient and 
Table 2. Comparison of patients with hip fracture by vitamin D status.

\begin{tabular}{|c|c|c|c|c|c|}
\hline \multirow[b]{2}{*}{ Clinical characteristics } & \multicolumn{3}{|c|}{ Mean $\pm \mathrm{SD} /$ number (percentage) } & \multirow[b]{2}{*}{$\begin{array}{c}p \text {-value } \\
(F \text {-statistic })\end{array}$} & \multirow[b]{2}{*}{ Scheffe post-hoc test } \\
\hline & $\begin{array}{l}\text { Vitamin D } \\
\text { deficiency } \\
(n=180)\end{array}$ & $\begin{array}{c}\text { Vitamin D } \\
\text { insufficiency } \\
\quad(n=84)\end{array}$ & $\begin{array}{l}\text { Vitamin D } \\
\text { sufficiency } \\
\quad(n=46)\end{array}$ & & \\
\hline Age & $80 \pm 10$ & $80 \pm 9.5$ & $81 \pm 9.2$ & $0.9(0.2)$ & - \\
\hline \multicolumn{4}{|l|}{ Gender } & & \\
\hline Male & $50(28 \%)$ & $22(26 \%)$ & $15(33 \%)$ & & \\
\hline Female & $130(72 \%)$ & $62(74 \%)$ & $31(67 \%)$ & & \\
\hline $25(\mathrm{OH}) \mathrm{D}$ value $(\mathrm{ng} / \mathrm{mL})$ & $12.3 \pm 4.4$ & $25 \pm 2.8$ & $39 \pm 7.7$ & & \\
\hline BMI & $23 \pm 3.6$ & $23 \pm 4.4$ & $21 \pm 2.8$ & $0.06(2.9)$ & - \\
\hline \multicolumn{4}{|l|}{ Fracture type $(n=309)$} & 0.6 & \\
\hline Extra-capsular fractures & $73(41 \%)$ & $32(38 \%)$ & $23(50 \%)$ & & \\
\hline Intra-capsular fractures & $106(59 \%)$ & $52(62 \%)$ & $23(50 \%)$ & & \\
\hline \multicolumn{4}{|l|}{ Previous hip fracture } & 0.3 & \\
\hline Yes & $7(3.9 \%)$ & $4(4.8 \%)$ & $0(0 \%)$ & & \\
\hline No & $173(96.1 \%)$ & $80(95.2 \%)$ & $46(100 \%)$ & & \\
\hline \multicolumn{6}{|l|}{ Underlying comorbidities } \\
\hline Hypertensions & $120(67 \%)$ & $48(57 \%)$ & $14(30 \%)$ & 0.2 & \\
\hline Diabetes mellitus & $39(22 \%)$ & $16(19 \%)$ & $11(24 \%)$ & 0.8 & \\
\hline Valvular heart disease & $31(17 \%)$ & $9(11 \%)$ & $9(20 \%)$ & 0.3 & \\
\hline Coronary artery disease & $34(19 \%)$ & $15(18 \%)$ & $3(6.5 \%)$ & 0.1 & \\
\hline Chronic kidney disease & $50(28 \%)$ & $22(26 \%)$ & $20(44 \%)$ & 0.08 & \\
\hline Stage IIIa & 24 & 13 & 10 & & \\
\hline Stage IIIb & 12 & 5 & 5 & & \\
\hline Stage IV & 8 & 2 & 2 & & \\
\hline Stage V & 6 & 2 & 3 & & \\
\hline Cerebral vascular accident & $25(14 \%)$ & $8(10 \%)$ & $7(15 \%)$ & 0.5 & \\
\hline Peptic ulcer history & $12(6.7 \%)$ & $9(11 \%)$ & $5(11 \%)$ & 0.5 & \\
\hline Viral hepatitis & $7(3.9 \%)$ & $5(6.0 \%)$ & $2(4.4 \%)$ & 0.7 & \\
\hline Dementia & $33(18 \%)$ & $14(17 \%)$ & $6(13 \%)$ & 0.7 & \\
\hline Affective or psychotic disorder & $11(6.1 \%)$ & $8(9.5 \%)$ & $0(0 \%)$ & 0.1 & \\
\hline Parkinsonism & $11(6.1 \%)$ & $4(4.8 \%)$ & $3(6.5 \%)$ & 0.9 & \\
\hline Cancer history & $26(14 \%)$ & $13(15 \%)$ & $3(6.5 \%)$ & 0.3 & \\
\hline Charlson Comorbidity Index & $4.9 \pm 1.9$ & $4.7 \pm 2.0$ & $4.6 \pm 1.8$ & $0.5(0.6)$ & - \\
\hline \multicolumn{6}{|l|}{ Laboratory parameters } \\
\hline Pre-operation $\mathrm{Hb}$ & $12 \pm 1.8$ & $12 \pm 1.7$ & $12 \pm 2.1$ & $0.4(0.8)$ & - \\
\hline Platelet & $215 \pm 91$ & $206 \pm 78$ & $205 \pm 99$ & $0.7(0.4)$ & - \\
\hline WBC & $13 \pm 36$ & $10 \pm 3.6$ & $9.6 \pm 3.0$ & $0.6(0.6)$ & - \\
\hline Creatinine (mg/dL) & $1.1 \pm 0.99$ & $1.7 \pm 6.7$ & $1.4 \pm 1.8$ & $0.4(1.0)$ & - \\
\hline eGFR & $81 \pm 36$ & $83 \pm 33$ & $69 \pm 35$ & $0.07(2.7)$ & - \\
\hline \multirow{2}{*}{$\begin{array}{l}\text { Parathyroid hormone level } \\
\quad(\mathrm{pg} / \mathrm{mL})(n=296)\end{array}$} & $(n=173)$ & $(n=79)$ & $(n=44)$ & $0.2(1.4)$ & - \\
\hline & $59 \pm 63$ & $50 \pm 42$ & $46 \pm 45$ & & \\
\hline $\begin{array}{c}\text { Hyperparathyroidism } \\
(\text { PTH }>65 \mathrm{pg} / \mathrm{mL})\end{array}$ & $39(23 \%)$ & $15(17.9 \%)$ & $4(9.1 \%)$ & 0.1 & \\
\hline \multirow{2}{*}{$\begin{array}{l}\text { Albumin level } \\
\quad(\mathrm{g} / \mathrm{dL})(n=308)\end{array}$} & $(n=179)$ & $(n=83)$ & $(n=46)$ & $0.006(5.3)$ & Vitamin D sufficiency \\
\hline & $3.0 \pm 0.38$ & $3.1 \pm 0.38$ & $3.2 \pm 0.35$ & & $\begin{array}{l}>\text { Vitamin D deficiency } \\
(p=0.02)\end{array}$ \\
\hline \multicolumn{4}{|l|}{ Pre-injury activities of daily living } & $0.6(0.5)$ & \\
\hline Barthel Index & $85 \pm 24$ & $86 \pm 22$ & $88 \pm 20$ & & - \\
\hline \multicolumn{4}{|l|}{ Pre-injury quality of life } & $0.7(0.4)$ & - \\
\hline EQ-5D score & $0.85 \pm 0.20$ & $0.86 \pm 0.20$ & $0.88 \pm 0.19$ & & \\
\hline Bone mineral density & $(n=173)$ & $(n=81)$ & $(n=46)$ & $0.3(1.1)$ & - \\
\hline T-score $(n=300)$ & $-3.8 \pm 1.2$ & $-3.7 \pm 1.1$ & $-3.5 \pm 1.1$ & & \\
\hline Diagnosis of sarcopenia & $(n=180)$ & $(n=84)$ & $(n=45)$ & 0.1 & \\
\hline Sarcopenia $(n=309)$ & $78(43 \%)$ & $32(38 \%)$ & $23(51 \%)$ & & \\
\hline \multirow{3}{*}{$\begin{array}{l}\text { Fat percentage }(\%) \\
\quad(n=275)\end{array}$} & $(n=158)$ & $(n=75)$ & $(n=42)$ & $0.02(4.1)$ & Vitamin D deficiency \\
\hline & $34 \pm 7.9$ & $34 \pm 7.7$ & $31 \pm 7.3$ & & $\begin{array}{l}>\text { Vitamin D sufficiency } \\
(p=0.02)\end{array}$ \\
\hline & & & & & $\begin{array}{l}\text { Vitamin D insufficiency } \\
>\text { Vitamin D sufficiency } \\
(p=0.048)\end{array}$ \\
\hline Living condition & & & & 0.2 & \\
\hline $\begin{array}{l}\text { Lives with family or in nursing } \\
\text { homes }\end{array}$ & $163(90.6 \%)$ & $81(96.4 \%)$ & $42(91.3 \%)$ & & \\
\hline Lives alone & $17(9.4 \%)$ & $3(3.6 \%)$ & $4(8.7 \%)$ & & \\
\hline Fracture season & & & & 0.6 & \\
\hline Spring & $68(38 \%)$ & $26(31 \%)$ & $18(39 \%)$ & & \\
\hline Summer & $38((21 \%)$ & $24(29 \%)$ & $11(24 \%)$ & & \\
\hline Fall & $33(18 \%)$ & $18(21 \%)$ & $11(24 \%)$ & & \\
\hline Winter & $41(23 \%)$ & $16(19 \%)$ & $6(13 \%)$ & & \\
\hline Fracture to operation interval & $(n=169)$ & $(n=75)$ & $(n=46)$ & 0.9 & \\
\hline (h) $(n=287)$ & $68 \pm 104$ & $59 \pm 184$ & $61 \pm 97$ & & \\
\hline
\end{tabular}

25(OH)D, 25-hydroxyvitamin D; BMI, body mass index; WBC, white blood cells; Hb, hemoglobin; eGFR, estimated glomerular filtration rate; PTH, parathyroid hormone; EQ-5D, EuroQol-5D. 
(A)
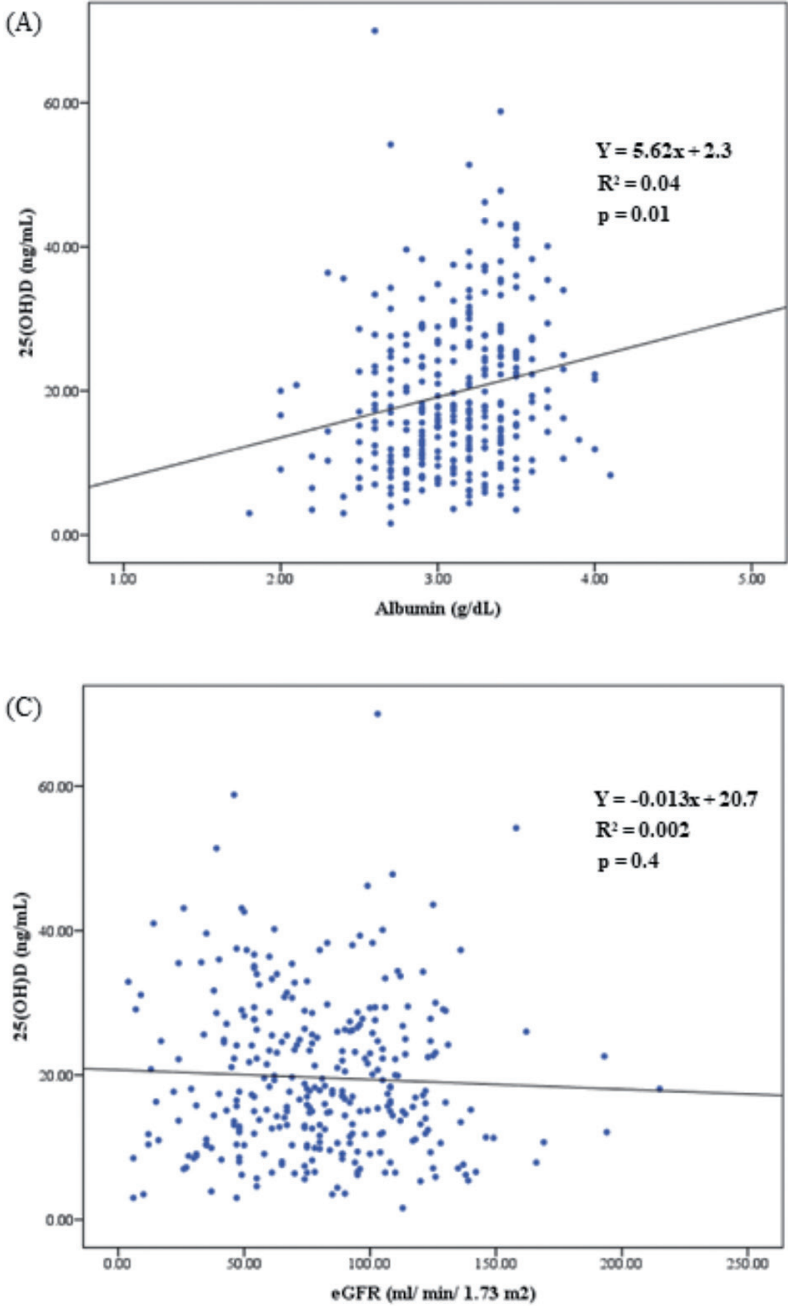

(B)

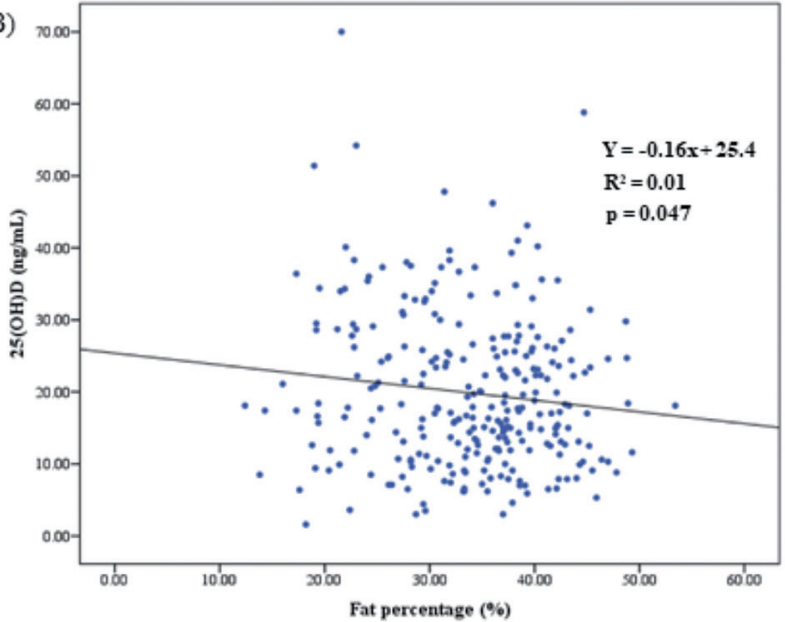

(D)

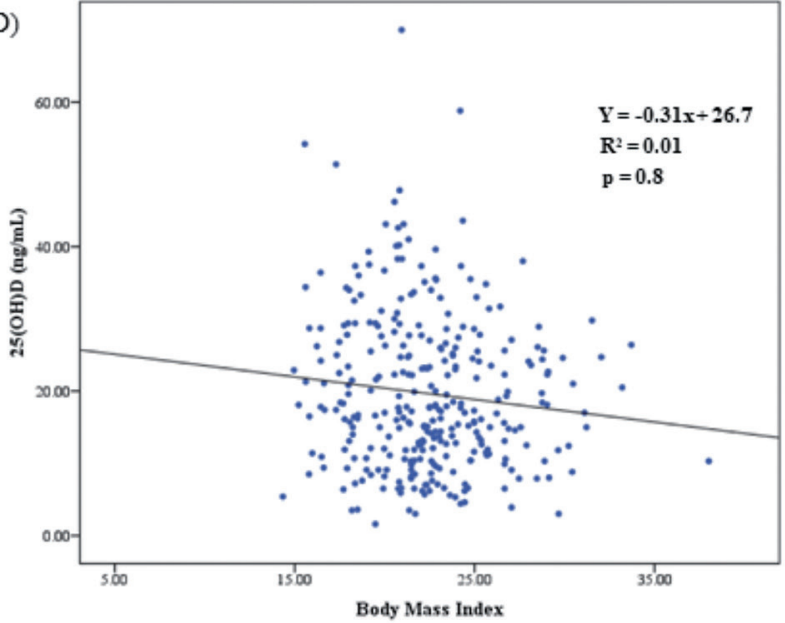

Fig. 1. Pearson correlation analysis of vitamin D concentration and four potential significantly related parameters. (A) albumin, (B) body fat percentage, (C) eGFR, and (D) BMI. eGFR, estimated glomerular filtration rate; BMI, body mass index.

deficient groups. The OR was $0.99(p=0.03)$, indicating that an increase in vitamin $\mathrm{D}$ would result in a slight reduction in the eGFR (Table 3 ).

\section{DISCUSSION}

Although Taiwan is located in a subtropical region and has plenty of sun exposure, epidemiological studies have demonstrated a high prevalence of vitamin D deficiency in healthy older adults. Chen et al. reported that the prevalence of vitamin D deficiency and insufficiency among 1,839 community-dwelling patients aged $\geq 50 \mathrm{y}$ was $33.6 \%$ and $50.5 \%$, respectively (14). Another large cohort study conducted in northern Taiwan recruited 3,954 participants aged $\geq 30$ y or above with normal kidney function and found $22.4 \%$ of them to have, which showed vitamin D deficiency (15). In comparison, our data indicated a much higher prevalence: $58.06 \%$ and $26.45 \%$ of all the participants had vitamin $\mathrm{D}$ deficiency and insufficiency, respectively. This finding agreed with the results of a meta-analysis conducted by Yao et al., who stated that an increase in $25(\mathrm{OH}) \mathrm{D}$ serum concentration was significantly associated with a reduction in hip fracture risk (16).
Vitamin D deficiency is particularly prevalent in older adults with hip fracture, but its prevalence varies among the studies conducted. In the present study, over half of the patients were deficient in vitamin D. Table 4 summarizes the results of studies conducted in the last two decades regarding the prevalence of vitamin D deficiency in older adults with hip fracture (17-27).

In the present study, despite the small disparity in mean albumin level between vitamin D sufficient and deficient groups was little, both univariate analysis and multinomial logistic regression analyses model revealed that serum albumin level was most significant risk factor for low serum 25(OH)D concentrations. The time interval between hip fracture occurrence and operation was not significantly different among the three groups, meaning that blood loss variation was not a cofounding factor. In addition, no significant intergroup differences were observed in viral hepatitis, coronary heart diseases, cancer history, or preoperative white blood cell counts, thereby excluding other possible etiologies of low serum albumin level. Therefore, malnutrition is the most likely explanation for the disparity in mean albumin and vitamin D levels in this study. The underlying 
Table 3. Multinomial logistic regression analysis of patients with hip fracture with vitamin D insufficiency and sufficiency compared with those with vitamin D deficiency.

\begin{tabular}{|c|c|c|c|c|c|}
\hline & \multirow{2}{*}{ Variables } & \multirow{2}{*}{ Odds ratio } & \multicolumn{2}{|c|}{$95 \% \mathrm{CI}$} & \multirow{2}{*}{$p$-value } \\
\hline & & & Lower limit & Upper limit & \\
\hline \multirow{5}{*}{$\begin{array}{l}\text { Vitamin D } \\
\text { insufficiency group }\end{array}$} & BMI & 1.01 & 0.92 & 1.11 & 0.8 \\
\hline & Albumin & 2.31 & 1.09 & 4.9 & 0.03 \\
\hline & eGFR & 1.00 & 0.99 & 1.01 & 0.8 \\
\hline & Fat percentage & 0.99 & 0.95 & 1.04 & 0.7 \\
\hline & $\begin{array}{l}\text { Affective or psychotic } \\
\text { disorder (No vs Yes) }\end{array}$ & 0.62 & 0.218 & 1.75 & 0.4 \\
\hline \multirow{5}{*}{$\begin{array}{l}\text { Vitamin D } \\
\text { sufficient group }\end{array}$} & BMI & 0.91 & 0.79 & 1.05 & 0.2 \\
\hline & Albumin & 4.03 & 1.42 & 11.4 & 0.009 \\
\hline & eGFR & 0.99 & 0.98 & 0.99 & 0.03 \\
\hline & Fat percentage & 0.95 & 0.89 & 1.01 & 0.1 \\
\hline & $\begin{array}{l}\text { Affective or psychotic } \\
\text { disorder (No vs Yes) }\end{array}$ & $1.228 \mathrm{E} 7$ & 0 & & 1.0 \\
\hline
\end{tabular}

The vitamin D deficient group served as the reference group in this model.

BMI, body mass index; CI, confidence interval; eGFR, estimated glomerular filtration rate.

mechanism linking low serum albumin level and vitamin D deficiency may be that most circulating $25(\mathrm{OH}) \mathrm{D}$ is tightly bound to DBP, with a smaller fraction (10$15 \%$ ) bound to albumin, and $<1 \%$ of circulating vitamin D is free and unbound (28). In addition, previous in vivo studies have suggested that DBP and albumin may act not only as transport proteins, but also as key determinants of the availability of $25(\mathrm{OH}) \mathrm{D}$ to 1 - $\alpha$-hydroxylase, which converts 25(OH)D into 1,25-hydroxyvitamin $\mathrm{D}\left[1,25(\mathrm{OH})_{2} \mathrm{D}\right]$, the bioactive form of vitamin $\mathrm{D}$ that has an effect at the cellular level $(29,30)$. This notion was corroborated in a clinical trial conducted by Lai et al. investigating 82 patients with liver cirrhosis; the findings revealed that low serum albumin level may result in impaired efficiency of the conversion of $25(\mathrm{OH}) \mathrm{D}$ to $1,25(\mathrm{OH})_{2} \mathrm{D}(31)$. Vitamin D deficiency can critically affect the prognosis of individuals with hip fracture; thus, studies have recommended active vitamin D deficiency surveillance in older adults with hip fracture and low serum albumin levels $(32,33)$.

Nutrition status critically affects patient outcomes after hip fracture. Significantly elevated mortality rate and decreased mobility have been observed after hip fracture in patients with reduced serum albumin level, malnutrition, or inadequate dietary intake (34-36). In addition to serum albumin, lymphocyte count may also be another simple laboratory test for evaluating malnutrition and predicting the prognosis of patients with hip fracture $(37,38)$. Diet affects hip fracture risk; in a prospective study that followed up 3,941 participants for approximately $10 \mathrm{y}$, meat eaters had significantly lower hip fracture risk than fish eaters, vegetarians, and vegans (39). In the same trial, meat eaters had significantly higher vitamin D intake and whole year 25(OH)D plasma concentration than the other three diet groups (40). Animal proteins contain various amino acids and are rich in vitamin $\mathrm{D}$, which restores bone collagen syn- thesis in fibroblasts and improves the calcium balance, leading to lower hip fracture risk in meat eaters compared with vegetarians and vegans (41).

A positive relationship between post-rehabilitation Barthel Index and vitamin D level has been reported by multiple studies, but few have investigated the association between patient preinjury functional status and vitamin D level (42). In the present study, the mean preinjury Barthel Index, EQ-5D score, and number of sarcopenia diagnoses were not significantly different between the three groups, indicating that all participants had comparable preinjury activities of daily livings. By contrast, a previous cross-sectional study reported that low albumin level $(<3.4 \mathrm{~g} / \mathrm{dL})$ and low preinjury Barthel Index were independently associated with vitamin D deficiency (43). We hypothesized that the vitamin D deficiency group participants in the prior research were older than those in the sufficient group, resulting in the disparity. In summary, the nonsignificant correlation between older adults' preinjury functional status and vitamin D deficiency observed in the present study indicated the differentiating older adults having sufficient serum 25(OH)D concentrations through functional daily activities is challenging.

The prevalence of functional hyperparathyroidism in individuals with hip fracture varies. Two recent cross-sectional studies have reported a prevalence of $68.9 \%$ and $40.91 \%$, respectively $(18,44)$. In a Japanese study of older adults with hip fracture, only $19.4 \%$ of participants had hyperparathyroidism (45), which was similar to the proportion in the present study, with only 58 of 296 patients having parathyroid hormone values $>65 \mathrm{pg} / \mathrm{mL}$. No significant intergroup difference was observed in mean parathyroid hormone level or number of patients with hyperthyroidism, likely because of insufficient sample size or variation in the timing of obtaining serum samples (46). 
Table 4. Comparison of studies on the prevalence of vitamin D deficiency in patients with hip fracture.

\begin{tabular}{|c|c|c|c|c|c|c|}
\hline Study & Beringer et al. & Bischoff-Ferrari et al. & . Dhanwal et al. & Gallacher et al. & Lakkireddy et al. & Moniz et al. \\
\hline Country, publication year & $\begin{array}{l}\text { United Kingdom, } \\
2006\end{array}$ & $\begin{array}{l}\text { Switzerland, } \\
2008\end{array}$ & India, 2013 & Scotland, 2005 & India, 2019 & $\begin{array}{l}\text { United Kingdom, } \\
2005\end{array}$ \\
\hline Participants number & 86 & 222 & 90 & 548 & 100 & 103 \\
\hline Age, mean \pm SD deviation & 65.3 & 85.7 & $65.9 \pm 12.6$ & 80.5 & $62.7 \pm 9.90$ & 73.4 \\
\hline Male, number (percentage) & 30.2 & 23 & 22.2 & 22 & & 20.4 \\
\hline \multicolumn{7}{|l|}{ Definition of } \\
\hline $\begin{array}{l}\text { vitamin D deficiency } \\
\text { vitamin D insufficiency }\end{array}$ & $\begin{array}{l}<50 \mathrm{nmol} / \mathrm{L} \\
50-70 \mathrm{nmol} / \mathrm{L}\end{array}$ & $\begin{array}{l}<30 \mathrm{nmol} / \mathrm{L} \\
30-74 \mathrm{nmol} / \mathrm{L}\end{array}$ & $<20 \mathrm{ng} / \mathrm{mL}$ & $\begin{array}{l}<50 \mathrm{nmol} / \mathrm{L} \\
50-70 \mathrm{nmol} / \mathrm{L}\end{array}$ & $\begin{array}{l}<20 \mathrm{ng} / \mathrm{mL} \\
20 \text { to } 30 \mathrm{ng} / \mathrm{mL}\end{array}$ & $\begin{array}{l}<50 \mathrm{nmol} / \mathrm{L} \\
50-70 \mathrm{nmol} / \mathrm{L}\end{array}$ \\
\hline $\begin{array}{l}\text { Overall vitamin D concen- } \\
\text { tration, mean } \pm \text { SD (ng/ } \\
\text { mL) }\end{array}$ & $21.0 \pm 23.4$ & $30.3 \pm 19.8 \mathrm{nmol} / \mathrm{L}$ & $15.3 \pm 9.4$ & 9.9 & $16.08 \pm 5.95$ & $12.9 \pm 7.8$ \\
\hline $\begin{array}{l}\text { Prevalence of vitamin D } \\
\text { deficiency, number } \\
\text { (percentage) }\end{array}$ & $48(55.8)$ & $131(59)$ & $69(76.7)$ & $502(91.6)$ & $65(65)$ & $84(81.6)$ \\
\hline $\begin{array}{l}\text { Prevalence of vitamin D } \\
\text { insufficiency, number } \\
\text { (percentage) }\end{array}$ & $15(17.5)$ & $82(37)$ & & $340(6.2)$ & $27(27)$ & $13(12.6)$ \\
\hline $\begin{array}{l}\text { Prevalence of hyperparathy- } \\
\text { roidism, percentage }\end{array}$ & & & 68.9 & & & 29.1 \\
\hline Reference & 22 & 25 & 18 & 24 & 19 & 23 \\
\hline Study & Niikura et al. & Phusunti et al. & Ramason et al. & Schweitzer et al. & Bakhtiyarova et al & \\
\hline Country, publication year & Japan, 2019 & Thailand, 2016 & Singapore, 2014 & Chile, 2016 & Russia, 2006 & \\
\hline Participants number & 360 & 379 & 412 & 228 & 64 & \\
\hline Age, mean \pm SD deviation & $84.7 \pm 8.2$ & $80.8 \pm 8.3$ & $79.8 \pm 9.1$ & $84 \pm 7$ & $68.8 \pm 9.5$ & \\
\hline Male, number (percentage) & 22.2 & 25.4 & 28.6 & 28 & & \\
\hline \multicolumn{7}{|l|}{ Definition of } \\
\hline $\begin{array}{l}\text { vitamin D deficiency } \\
\text { vitamin D insufficiency }\end{array}$ & $\begin{array}{l}<20 \mathrm{ng} / \mathrm{mL} \\
20 \text { to } 30 \mathrm{ng} / \mathrm{mL}\end{array}$ & $\begin{array}{l}<20 \mathrm{ng} / \mathrm{mL} \\
20 \text { to } 30 \mathrm{ng} / \mathrm{mL}\end{array}$ & $\begin{array}{l}<20 \mathrm{ng} / \mathrm{mL} \\
20 \text { to } 30 \mathrm{ng} / \mathrm{mL}\end{array}$ & $\begin{array}{l}<20 \mathrm{ng} / \mathrm{mL} \\
20 \text { to } 30 \mathrm{ng} / \mathrm{mL}\end{array}$ & $\begin{array}{l}<25 \mathrm{nmol} / \mathrm{L} \\
25-40 \mathrm{nmol} / \mathrm{L}\end{array}$ & \\
\hline $\begin{array}{l}\text { Overall vitamin D concen- } \\
\text { tration, mean } \pm \text { SD (ng/ } \\
\text { mL) }\end{array}$ & $16.5 \pm 7.2$ & & 19.1 & & $22.4 \pm 11.4 \mathrm{nmol} / \mathrm{L}$ & \\
\hline $\begin{array}{l}\text { Prevalence of vitamin D } \\
\text { deficiency, number } \\
\text { (percentage) }\end{array}$ & $258(71.7)$ & $124(46.3)$ & $237(57.5)$ & $183(80)$ & $42(65)$ & \\
\hline $\begin{array}{l}\text { Prevalence of vitamin D } \\
\text { insufficiency, number } \\
\text { (percentage) }\end{array}$ & $80(22.2)$ & $86(32.1)$ & $142(34.5)$ & $39(18)$ & $16(24)$ & \\
\hline $\begin{array}{l}\text { Prevalence of hyperparathy- } \\
\text { roidism, percentage }\end{array}$ & & 31.5 & & & & \\
\hline Reference & 20 & 17 & 21 & 27 & 26 & \\
\hline
\end{tabular}

Equation used for vitamin D unit transformation: $\mathrm{ng} / \mathrm{mL} \times 2.496=\mathrm{nmol} / \mathrm{L}$.

Several observational studies involving the general population have reported that body fat percentage and BMI are inversely correlated with serum 25(OH)D concentrations (47), a finding similar to ours (Fig. 1). In a study involving 410 healthy women, serum 25(OH)D concentrations progressively decreased with an increase in body fat percentage, and the difference in serum 25(OH)D concentration between participants with the highest and lowest quartiles of body fat percentage was significant (48). The effect of fat on serum 25(OH)D may be explained by its role as a reservoir for lipid-soluble vitamin $D$. The release of vitamin $D$ from fat is extremely slow and proportional to the vitamin's concentration in adipose tissue (49). Because most partici- pants in this study were lean (the mean BMI was between 21 and 22), the impact of body fat percentage on vitamin $\mathrm{D}$ deficiency may have been negligible in the multinomial logistic regression analysis.

A significant association between vitamin D concentrations and lower eGFR was observed in the sufficient group, consistent with the finding of a nationwide Korean study of 11,336 patients, in which the eGFR decreased significantly with increasing 25(OH)D concentrations. Notably, the vitamin D concentrations of patients with early stage chronic kidney disease (CKD) were comparable with those of participants with normal eGFRs, but vitamin D concentration started decreasing in patients with CKD stage $\leq 3 \mathrm{~b}$ (50). Simi- 
larly, in a US study comparing participants with normal kidney function, the adjusted mean serum 25(OH)D concentrations was elevated in participants with slightly and severely decreased kidney function (eGFR, 60-89 and $15-29 \mathrm{~mL} / \mathrm{min} / 1.73 \mathrm{~m}^{2}$ ), respectively (51). CKD may decrease vitamin D production and affect vitamin D metabolism. Bosworth et al. assessed the correlation between the eGFR and level of 24,25-dihydroxyvitamin D $\left[24,25(\mathrm{OH})_{2} \mathrm{D}\right]$, the first metabolite of $25(\mathrm{OH}) \mathrm{D}$ by the enzyme CYP24A1. Concentration of $24,25(\mathrm{OH})_{2} \mathrm{D}$ was positively correlated with the eGFR. Therefore, decreased vitamin D catabolism and $25(\mathrm{OH}) \mathrm{D}$ production indicate stagnation of vitamin D metabolism in patients with CKD, particularly those with early stage CKD (52). In the present study, the vitamin D sufficient group had the highest proportion of patients with stage $3 \mathrm{a}$ and $3 \mathrm{~b}$ CKD $(32.6 \%)$; the proportions were $20 \%$ and $21.4 \%$ in the insufficient and deficient groups, respectively (Table 2). Thus, the sufficient group might have had both vitamin D sufficiency and lower eGFR. Future studies should include a larger number of participants with vitamin D-sufficiency group to confirm this finding.

\section{LIMITATIONS}

This study has several limitations. First, only 310 participants were enrolled, and they may not represent all older adults with hip fracture in Taiwan. Second, this study was conducted in the metropolitan area Taipei City, and the findings may thus not represent the epidemiology of hip fracture in all urban areas in Taiwan. Third, some data were missing despite our comprehensive review of patient data. Thirty-five of 310 values were missing for body fat percentage. Fourth, the effect of vitamin D concentrations on serum calcium or phosphate could not be determined because those data were unavailable. Finally, data were only collected before hip fracture surgery. Additional studies and long-term follow-up are required to follow the natural course and assess the clinical effect of vitamin D deficiency on this specific cohort.

\section{CONCLUSION}

The prevalence of vitamin D deficiency was high in this cohort of older Taiwanese adults with hip fracture. Reduced serum albumin level was found in both the univariate and multinomial logistic regression model, indicating that malnutrition was the most significant risk factor for vitamin D deficiency. In addition, preinjury activities of daily living were not found to be a good predictor of vitamin D deficiency. The relationship between vitamin $\mathrm{D}$ and each eGFR domain remains unclear and warrants further research. Our findings may help establish a robust screening and treatment program for vitamin D deficiency that could improve functional outcomes and reduce the risk of mortality in older adults with hip fracture.

\section{Authorship}

Conception and design of study: YP Chen, YJ Kuo, and MH Chiang, acquisition of data: YP Chen, YJ Kuo, WC Chang, and $\mathrm{Y} \mathrm{Wu}$, analysis and/or interpretation of data: MH Chiang, WC Chang, and YC Lin, drafting the manuscript: MH Chiang and YC Jang, revising the manuscript: YP Chen, YJ Kuo, and YC Lin.

MH Chiang and YJ Kuo contributed equally as first authors.

\section{Disclosure of state of COI}

Ming-Hsiu Chiang, Yi-Jie Kuo, Wei-Chun Chang, Yueh $\mathrm{Wu}$, Ying-Chin Lin, Yeu-Chai Jang, and Yu-Pin Chen declared no conflicts of interest in this study.

\section{Acknowledgments}

The authors are grateful to Wan Fang Hospital (grant 109-wf-eva-11 and grant 108-wf-eva-22) for financially supportive this research and would like to acknowledge the Laboratory Animal Center at TMU for the English editing support.

\section{REFERENCES}

1) Katsoulis M, Benetou V, Karapetyan T, Feskanich D, Grodstein F, Pettersson-Kymmer U, Eriksson S, Wilsgaard T, Jorgensen L, Ahmed LA, Schottker B, Brenner H, Bellavia A, Wolk A, Kubinova R, Stegeman B, Bobak M, Boffetta P, Trichopoulou A. 2017. Excess mortality after hip fracture in elderly persons from Europe and the USA: the CHANCES project. J Intern Med 281: 300310.

2) Cheung CL, Ang SB, Chadha M, Chow ES, Chung YS, Hew FL, Jaisamrarn U, Ng H, Takeuchi Y, Wu CH, Xia W, Yu J, Fujiwara S. 2018. An updated hip fracture projection in Asia: The Asian Federation of Osteoporosis Societies study. Osteoporos Sarcopenia 4: 16-21.

3) Chen IJ, Chiang CY, Li YH, Chang CH, Hu CC, Chen DW, Chang Y, Yang WE, Shih HN, Ueng SW, Hsieh PH. 2015. Nationwide cohort study of hip fractures: time trends in the incidence rates and projections up to 2035. Osteoporos Int 26: 681-688.

4) Di Monaco M, Castiglioni C, Tappero R. 2016. Parathyroid hormone response to severe vitamin D deficiency is associated with femoral neck bone mineral density: an observational study of 405 women with hip-fracture. Hormones (Athens) 15: 527-533.

5) Carrillo Gonzalez I, Martinez-Ramirez MJ, Tenorio Jimenez C, Delgado Martinez AD, Aguilar Pena R, Madrigal Cueto R, Delgado-Rodriguez M. 2020. 25-Hydroxyvitamin D levels in the early healing of osteoporotic hip fracture and their relationship with clinical outcome. Nutr Hosp 37: 327-334.

6) Bischoff-Ferrari HA, Dietrich T, Orav EJ, Hu FB, Zhang Y, Karlson EW, Dawson-Hughes B. 2004. Higher 25-hydroxyvitamin D concentrations are associated with better lower-extremity function in both active and inactive persons aged $>$ or $=60$ y. Am J Clin Nutr 80: $752-758$.

7) Lv QB, Gao X, Liu X, Shao ZX, Xu QH, Tang L, Chi YL, Wu AM. 2017. The serum 25-hydroxyvitamin D levels and hip fracture risk: a meta-analysis of prospective cohort studies. Oncotarget 8: 39849-39858.

8) Abdel-Wareth L, Haq A, Turner A, Khan S, Salem A, Mustafa F, Hussein N, Pallinalakam F, Grundy L, Patras G, Rajah J. 2013. Total vitamin D assay comparison of 
the Roche Diagnostics "Vitamin D total" electrochemiluminescence protein binding assay with the Chromsystems HPLC method in a population with both D2 and D3 forms of vitamin D. Nutrients 5: 971-980.

9) Holick MF. 2007. Vitamin D deficiency. $N$ Engl J Med 357: 266-281.

10) Chi I, Boey KW. 1993. Hong Kong validation of measuring instruments of mental health status of the elderly. Clin Gerontol 13: 35-51.

11) EuroQol Group. 1990. EuroQol-a new facility for the measurement of health-related quality of life. Health Policy 16: 199-208.

12) Mahoney FI, Barthel DW. 1965. Functional evaluation: the Barthel Index. Md State Med J 14: 61-65.

13) Chen LK, Liu LK, Woo J, Assantachai P, Auyeung TW, Bahyah KS, Chou MY, Chen LY, Hsu PS, Krairit O, Lee JS, Lee WJ, Lee Y, Liang CK, Limpawattana P, Lin CS, Peng LN, Satake S, Suzuki T, Won CW, Wu CH, Wu SN, Zhang T, Zeng P, Akishita M, Arai H. 2014. Sarcopenia in Asia: consensus report of the Asian Working Group for Sarcopenia. J Am Med Dir Assoc 15: 95-101.

14) Chen CH, Liu LK, Chen MJ, Lee WJ, Lin MH, Peng LN, Chen LK. 2018. Associations between vitamin D deficiency, musculoskeletal health, and cardiometabolic risk among community-living people in Taiwan: Age and sex-specific relationship. Medicine (Baltimore) 97: e13886.

15) Lee MJ, Hsu HJ, Wu IW, Sun CY, Ting MK, Lee CC. 2019. Vitamin D deficiency in northern Taiwan: a community-based cohort study. BMC Public Health 19: 337.

16) Yao P, Bennett D, Mafham M, Lin X, Chen Z, Armitage J, Clarke R. 2019. Vitamin D and calcium for the prevention of fracture: a systematic review and meta-analysis. JAMA Netw Open 2: e1917789.

17) Phusunti S, Suthutvoravut W, Unnanuntana A, Chotiyarnwong P. 2016. The prevalence of hypovitaminosis $\mathrm{D}$ in patient with fragility hip fracture at a single institution in Thailand. J Med Assoc Thai (Chotmaihet thangphaet) 99: 1233-1238.

18) Dhanwal DK, Sahoo S, Gautam VK, Saha R. 2013. Hip fracture patients in India have vitamin D deficiency and secondary hyperparathyroidism. Osteoporos Int 24: 553-557.

19) Lakkireddy M, Mudavath SV, Karra ML, Arora AJ. 2019. Hypovitaminosis D in patients with osteoporotic hip fractures. J Clin Orthop Trauma 10: 768-773.

20) Niikura T, Oe K, Sakai Y, Iwakura T, Fukui T, Nishimoto H, Hayashi S, Matsumoto T, Matsushita T, Maruo A, Yagata Y, Kishimoto K, Sakurai A, Kuroda R. 2019. Insufficiency and deficiency of vitamin D in elderly patients with fragility fractures of the hip in the Japanese population. J Orthop Surg (Hong Kong) 27: 2309499019877517.

21) Ramason R, Selvaganapathi N, Ismail NH, Wong WC, Rajamoney GN, Chong MS. 2014. Prevalence of vitamin D deficiency in patients with hip fracture seen in an orthogeriatric service in sunny Singapore. Geriatric Orthopaedic Surg Rehabil 5: 82-86.

22) Beringer T, Heyburn G, Finch M, McNally C, McQuilken M, Duncan M, Dixon T. 2006. Prevalence of vitamin D inadequacy in Belfast following fragility fracture. Curr Med Res Opin 22: 101-105.

23) Moniz C, Dew T, Dixon T. 2005. Prevalence of vitamin D inadequacy in osteoporotic hip fracture patients in London. Curr Med Res Opin 21: 1891-1894.
24) Gallacher SJ, McQuillian C, Harkness M, Finlay F, Gallagher AP, Dixon T. 2005. Prevalence of vitamin D inadequacy in Scottish adults with non-vertebral fragility fractures. Curr Med Res Opin 21: 1355-1361.

25) Bischoff-Ferrari HA, Can U, Staehelin HB, Platz A, Henschkowski J, Michel BA, Dawson-Hughes B, Theiler R. 2008. Severe vitamin D deficiency in Swiss hip fracture patients. Bone 42: 597-602.

26) Bakhtiyarova S, Lesnyak O, Kyznesova N, Blankenstein MA, Lips P. 2006. Vitamin D status among patients with hip fracture and elderly control subjects in Yekaterinburg, Russia. Osteoporos Int 17: 441-446.

27) Schweitzer D, Amenábar PP, Botello E, López M, Saavedra Y, Klaber I. 2016. Vitamin D levels among Chilean older subjects with low energy hip fracture. Rev Med Chil 144: 175-180.

28) Yousefzadeh P, Shapses SA, Wang X. 2014. Vitamin D binding protein impact on 25-hydroxyvitamin D levels under different physiologic and pathologic conditions. Int J Endocrinol 2014: 981581.

29) Hewison M, Zehnder D, Bland R, Stewart PM. 2000. 1alpha-Hydroxylase and the action of vitamin D. J Mol Endocrinol 25: 141-148.

30) Jassil NK, Sharma A, Bikle D, Wang X. 2017. Vitamin D binding protein and 25-hydroxyvitamin D levels: emerging clinical applications. Endocr Pract 23: 605-613.

31) Lai JC, Bikle DD, Lizaola B, Hayssen H, Terrault NA, Schwartz JB. 2015. Total $25(\mathrm{OH})$ vitamin D, free $25(\mathrm{OH})$ vitamin $\mathrm{D}$ and markers of bone turnover in cirrhotics with and without synthetic dysfunction. Liver Int 35: 2294-2300.

32) Sprague S, Slobogean GP, Bogoch E, Petrisor B, Garibaldi A, O'Hara N, Bhandari M, FAITH Investigators. 2017. Vitamin D use and health outcomes after surgery for hip fracture. Orthopedics 40: e868-e875.

33) Hao L, Carson JL, Schlussel Y, Noveck H, Shapses SA. 2020. Vitamin D deficiency is associated with reduced mobility after hip fracture surgery: a prospective study. Am J Clin Nutr 112: 613-618.

34) Higashikawa T, Shigemoto K, Goshima K, Horii T, Usuda D, Morita T, Moriyama M, Inujima H, Hangyou M, Usuda K, Morimoto S, Matsumoto T, Takashima S, Kanda T, Okuro M, Sawaguchi T. 2020. Mortality and the risk factors in elderly female patients with femoral neck and trochanteric fractures. J Clin Med Res 12: 668-673.

35) Helminen H, Luukkaala T, Saarnio J, Nuotio M. 2017. Comparison of the Mini-Nutritional Assessment short and long form and serum albumin as prognostic indicators of hip fracture outcomes. Injury 48: 903-908.

36) Huang Z, Himes JH, McGovern PG. 1996. Nutrition and subsequent hip fracture risk among a national cohort of white women. Am J Epidemiol 144: 124-134.

37) Koval KJ, Maurer SG, Su ET, Aharonoff GB, Zuckerman JD. 1999. The effects of nutritional status on outcome after hip fracture. J Orthop Trauma 13: 164-169.

38) Li S, Zhang J, Zheng H, Wang X, Liu Z, Sun T. 2019. Prognostic role of serum albumin, total lymphocyte count, and mini nutritional assessment on outcomes after geriatric hip fracture surgery: a meta-analysis and systematic review. J Arthroplasty 34: 1287-1296.

39) Tong TYN, Appleby PN, Armstrong MEG, Fensom GK, Knuppel A, Papier K, Perez-Cornago A, Travis RC, Key TJ. 2020. Vegetarian and vegan diets and risks of total and site-specific fractures: results from the prospective 
EPIC-Oxford study. BMC Med 18: 353.

40) Crowe FL, Steur M, Allen NE, Appleby PN, Travis RC, Key TJ. 2011. Plasma concentrations of 25-hydroxyvitamin $\mathrm{D}$ in meat eaters, fish eaters, vegetarians and vegans: results from the EPIC-Oxford study. Public Health Nutr 14: 340-346.

41) Lousuebsakul-Matthews V, Thorpe DL, Knutsen R, Beeson WL, Fraser GE, Knutsen SF. 2014. Legumes and meat analogues consumption are associated with hip fracture risk independently of meat intake among Caucasian men and women: the Adventist Health Study-2. Public Health Nutr 17: 2333-2343.

42) Di Monaco M, Castiglioni C, Di Carlo S, La Marmora E, Filipovic I, Milano E, Minetto MA, Massazza G. 2019. Classes of vitamin D status and functional outcome after hip fracture: a prospective, short-term study of 1350 inpatients. Eur J Phys Rehabil Med 55: 56-62.

43) Larrosa M, Casado E, Gomez A, Moreno M, Berlanga E, Ramon J, Gratacos J. 2008. Vitamin D deficiency and related factors in patients with osteoporotic hip fracture. Med Clin (Barc) 130: 6-9.

44) Dadra A, Aggarwal S, Kumar P, Kumar V, Dibar DP, Bhadada SK. 2019. High prevalence of vitamin D deficiency and osteoporosis in patients with fragility fractures of hip: A pilot study. J Clin Orthop Trauma 10: 1097-1100.

45) Sakuma M, Endo N, Oinuma T, Hayami T, Endo E, Yazawa T, Watanabe K, Watanabe S. 2006. Vitamin D and intact PTH status in patients with hip fracture. Osteoporos Int 17: 1608-1614.
46) Ng K, St John A, Bruce DG. 1994. Secondary hyperparathyroidism, vitamin D deficiency and hip fracture: importance of sampling times after fracture. Bone Miner 25: 103-109.

47) Liu B, Fan D, Yin F. 2020. The relationship between vitamin D status and visceral fat accumulation in males with type 2 diabetes. J Nutr Sci Vitaminol 66: 396-401.

48) Arunabh S, Pollack S, Yeh J, Aloia JF. 2003. Body fat content and 25-hydroxyvitamin D levels in healthy women. J Clin Endocrinol Metab 88: 157-161.

49) Rosenstreich SJ, Rich C, Volwiler W. 1971. Deposition in and release of vitamin D3 from body fat: evidence for a storage site in the rat. J Clin Invest 50: 679-687.

50) Park J, Ryu SY, Han MA, Choi SW. 2016. The association of vitamin D with estimated glomerular filtration rate and albuminuria: 5th Korean National Health and Nutritional Examination Survey 2011-2012. J Ren Nutr 26: 360-366.

51) Chonchol M, Scragg R. 2007. 25-Hydroxyvitamin D, insulin resistance, and kidney function in the Third National Health and Nutrition Examination Survey. Kidney Int 71: 134-139.

52) Bosworth CR, Levin G, Robinson-Cohen C, Hoofnagle AN, Ruzinski J, Young B, Schwartz SM, Himmelfarb J, Kestenbaum B, de Boer IH. 2012. The serum 24,25-dihydroxyvitamin D concentration, a marker of vitamin D catabolism, is reduced in chronic kidney disease. Kidney Int 82: 693-700. 